\title{
Интерференционные и дифракционные алмазные оптические элементы для управления мощными лазерными пучками ИК диапазона
}

\author{
В.С. Павельев ${ }^{1,2 *}$, М.С. Комленок ${ }^{3,4}$, П.А. Пивоваров ${ }^{3,4}$, Б.О. Володкин ${ }^{1}$, \\ К.Н. Тукмаков ${ }^{1}$, В.И. Анисимов ${ }^{5}$, В.В. Бутузов ${ }^{5}$, В.Р.Сороченко ${ }^{3}$, \\ С.М. Нефедов ${ }^{3}$, А.П.Минеев ${ }^{3}$, В.А. Сойфер ${ }^{1,2}$, В.И. Конов ${ }^{3,4}$ \\ ${ }^{1}$ Самарский университет \\ ${ }^{2}$ Институт систем обработки изображений РАН, г. Самара \\ ${ }^{3}$ Институт общей физики им. А.М. Прохорова РАН, г. Москва \\ ${ }^{4}$ Национальный исследовательский ядерный университет «МИФИ», г. Москва \\ 5 АО “НИИ “Экран”, г. Самара \\ *E-mail: pavelyev10@mail.ru
}

DOI:10.31868/RFL2018.178-179

Сочетание высокой прозрачности с рекордной теплопроводностью и слабой зависимостью показателя преломления от температуры делают алмаз исключительно перспективным материалом для создания силовых оптических элементов ИК-диапазона. Достижения в области синтеза поликристаллических алмазных пластин позволяют получать пластины с толщиной до 1 мм и диаметром до 100 мм. Это сделало возможным появление алмазных выходных окон, делителей пучка, дифракционных оптических элементов (ДОЭ) для управления излучением мощных лазеров ИК-диапазона. В [1,2] представлены результаты исследования дифракционных оптических элементов, изготовленных с помощью технологий лазерной абляции и плазмохимического травления. В [2] представлены результаты исследования алмазных фокусаторов излучения $\mathrm{CO}_{2}$-лазера в заданные двумерные фокальные области. Экспериментально было показано, что применение лазерной абляции поверхности алмазной подложки позволяет создавать элементы с многоуровневым дифракционным микрорельефом, что позволяет создавать фокусирующие элементы с дифракционной эффективностью более $87 \%$ (после нанесения антиотражающего покрытия). Применение плазмохимического травления алмазных подложек позволяет создавать дифракционные оптические элементы со ступенчатым микрорельефом (в частности, дифракционные решетки) [2].

Недостатком алмазных оптических элементов является высокая оптическая плотность алмаза (показатель преломления $n=2.4$ ), которая приводит к значительным френелевским потерям, что объясняет актуальность разработки технологии нанесения антиотражающих покрытий на алмазные подложки.

В работе [3] приведены результаты исследования многослойного антиотражающего покрытия для алмазной подложки с максимальным пропусканием в диапазоне 8-12 мкм. Экспериментально показано, что алмазная плоскопараллельная пластина с двусторонним антиотражающим покрытием [3] обладает пропусканием не менее $94 \%$ в указанном диапазоне.

Настоящая работа посвящена исследованию формирования дифракционного микрорельефа на алмазной подложке с помощью эффективной технологии плазмохимического травления, основанной на применении Бош- 
процесса, а также исследованию технологии создания и свойств многослойных интерференционных покрытий на поверхности алмазных подложек.

\section{Литература}

[1] V.V. Kononenko, V.I. Konov et al, Diamond diffraction optics for $\mathrm{CO}_{2}$ lasers. Quantum Electronics 29(1), 9-10 (1999)

[2] V.S. Pavelyev, V.A. Soifer et al, Diffractive microoptics for technological IR-lasers. book: "HighPower and Femtosecond Lasers: Properties, Materials and Applications", Editors: Paul-Henri Barret and Michael Palmer.-Nova Science Publishers, Inc, 125-158 (2009)

[3] M.S. Komlenok, P.A. Pivovarov et al, High-damage-threshold antireflection coatings on diamond for $\mathrm{CW}$ and pulsed $\mathrm{CO}_{2}$ lasers, Laser Physics Letters 15, 036001 (2018) 